\title{
The Effect of Financial Distress, Management Turnover, Audit Opinion and Reputation of Public Accounting Firm to Auditor Switching
}

\author{
Atika Zarefar ${ }^{1} \quad$ Vera Oktari $^{2} \quad$ Arumega Zarefar ${ }^{2}$ \\ 1.Politeknik Caltex Riau, Po box 28293, Riau, Indonesia \\ 2.Riau University, Po box 28293, Riau, Indonesia
}

\begin{abstract}
This research aimed to determine the effect of financial distress, management turnover, audit opinion, and reputation of public accounting firm to uditor switching in all companies registered in Indonesia Stock Exchange during the period of 2014 - 2017. Methodology Approach - This research uses Logistic Regression analysis. This research uses 260 companies with an observation period of 4 years as the samples and the test results show that financial distress has an effect on auditor switching with significant value of $0.049<0.05$, management turnover has an effect on auditor switching with significant value of $0.03<0.05$, audit opinion has an affect on auditor switching with significant value $0.021<0.05$ and the reputation of public accounting firm on auditor switching with significant value $0,034<0,05$. The results presented in this research have important implications on audit profession and regulators in Indonesia.
\end{abstract}

Keywords: Financial Distress, Management Turnover, Audit Opinion And Reputation of Public Accounting Firm.

DOI: $10.7176 /$ RJFA/10-22-11

Publication date: November $30^{\text {th }} 2019$

\section{Introduction}

Financial statements are accountability reports of a company or management to interested parties related to the condition of the company in certain periods i.e shareholders, government, creditors, and other related interested parties. Financial statements describe the information about the financial condition of a company. Financial statements are one of the tools used to account for management activities inside which contain financial activities records to communicate the facts about a company.

Financial statements have the information needed by both internal and external parties as the basis for decision making. Internal parties refer to the company's management in determining both short term and long term policies. Reliable information from the management regarding the fund accountability invested and other information used as the basis of decision making is very needed by the external parties like shareholders, creditors, potential investors, tax office, and labor union. Thus, financial statements must be examined by an independent auditor to provide audit opinion and is in accordance with Generally Accepted Accounting Principles. Independent auditor has a function to conduct an objective examination and provide an opinion for the reasonableness of the financial statements presented the by the company's management. Other independent auditors have the roles to ensure that financial statements are presented accurately and the auditor is considered able to overcome the conflict of interests between the principle (shareholders) and the agents, which are the management as the company manager. Therefore, every go public company must publish their financial statements in accordance with the actual condition in order to produce reliable financial statements.

The turnover message of Public Accounting Firm is motivated by the Enron case encountered in the United States in 2001. Arthur Anderson as the auditor in charge of Enron financial statements have failed to maintain it's independence. In this case, there is a moral violation which is manipulating financial statements by recording 600 million US Dollar, although Enron company suffered losses at that time. Starting with this case, then US government make a regulations regarding to auditor rotation that is described in Sarbanes Oxley Act (SOX). Indonesia is one of the countries that is affected by that case, Indonesia is a country that requires companies to conduct auditor switching which is regulated in the Decree of Minister of Finance of the Republic of Indonesia Number 17 / PMK.01 / 2008 regarding Public Accounting Services. In Article 3 paragraph 1, the Regulation of Minister of Finance in 2008 mentioned that the provision of general audit services in one entity is conducted by Public Accounting Firm maximum 6 (six) years respectively and by a certified public accountant maximum three (3) years respectively on the same client. However, the rules regarding the change of auditor is updated with the issuance of Government Regulation Number 20 Year 2015 about the practice of public accountant which stated that general audit services of financial statements of an entity has no longer restrictions for Public Accounting Firm. The restriction only applies to public accountant, which is five (5) years respectively.

Auditor Switching can be mandatory or voluntary. Auditor Switching which is mandatory occurs because of the required rules. While voluntary can happen because of a reason or there are certain factors from the 
company's clients or that Public Accounting Firm. Auditor Switching is very interested to be examined because there are many causative factors, especially if auditor change happens outside the rules. In this research, the causative factors of Auditor Switching are financial distress, management turnover, audit opinion and reputation of Public Accounting Firm.

\section{Literature Review}

\subsection{Agency theory}

Jensen and Meckling (1976) stated that the relationship between shareholders (principal) and managers occurs when the shareholders (principal) appoint a manager (agent) as a manager and decision maker for the company. Manager develops moral responsibility to optimize shareholders interest (principal). However, on the other hand, the manager also has a goal to maximize the welfare and interests so that there is a possibility that the agent does not always act in the best interests of the principal.

Agency theory provides an explanation about agency conflict and asymmetric information between the principle and agent. This theory is used in various kinds of social researches. The agency relationship is known as a contract between two parties to carry out a job. Asymmetric information between one party and other parties must be assisted by a third party or mediator, which is an independent external auditor that is considered able to overcome the principal and the agent in managing the company.

The task of an auditor is to provide opinion on the audited financial statements that have been made on the fairness of financial statements made by the principal to consider the going concern of the audited company (SPAP PSA Number 30 AU section 341, 2011).

According to Eisenhardt (1989), agency theory is implemented by three assumptions, such as:

a. Assumption regarding to human nature, that human has a nature to be self-interest, have bounded rationality, and dislike risk aversion.

b. Assumption regarding to organization, is the conflict between the members of organization, efficiency as the criteria of it's productivity.

c. Assumption regarding to information is that the information is viewed as a marketable commodity goods. Based on these conditions, the managers tend to act opportunistically, which the manager will give priority to self interest, this is what triggers agency conflict so that auditor is needed to act as an independent party.

\subsection{Auditing (Auditing)}

According to Agoes (2012: 4), the definition of auditing is an inspection made critically and systematically, by an independent party, to the financial statements prepared by the management, along with the copy of records and supporting evidences, in order to be able to give an opinion about the fairness of the financial statements.

According to Arens et al. (2012: 4), Auditing is the accumulation and evolution of evidence about information to determine and report on the degree of correspondence between the information and established criteria. Auditing should be done by a competent, independent person.

Then, it can be concluded that auditing is a critical and systematic process to evaluate the financial statements prepared by the management objectively along with a copy of records and evidences based on economic events occured conducted by independent auditor with the purpose to determine the level of conformity and fairness between information and the established criteria, then the results are submitted to the interested parties.

2.3 Regulation of the Minister of Finance of the Republic of Indonesia regarding "Public Accountant Services" Indonesia is one of the countries that requires accounting firms turnover and audit partners which is applied periodically. The regulation about this turnover has emerged in 2002 in the form of the Decree of Minister of Finance. In 2003, that 2002 Decree was amended with the Decree of Minister of Finance Number 359 / KMK.06 / 2003.

Then on February 5, 2008, the Minister of Finance issued Regulation of the Minister of Finance Number 17 / PMK.01 / 2008 about "Public Accountant Services" Article 3. This newest regulation arranges about granting general audit services of the financial statements of an entity conducted by Public Accounting Firm maximum 6 (six) years respectively, and by a public accountant maximum 3 (three) years respectively. Public accountant and accounting firm may receive the assignment back after not providing general audit services of that client's financial statements for a year.

However, since April 6, 2015, the government has issued Government Regulation (PP) No.20 of 2015 about the practice of public accounting which is a further arrangement of Constitution Number 5 Year 2011 regarding Public Accountant. This government regulation shall be effective from April 6, 2015. If previously, according to the Minister of Finance, a Public Accounting Firm is restricted only able to audit the company's historical financial statements within 6 (six) years respectively and the longest is within three (3) years respectively, then 
based on this new government regulation has no longer restrictions for Public Accounting Firm. The restriction only applies to public accountant, which is 5 years respectively.

Regulation of the Minister of Finance and Government Regulation is used as the theoretical basis because it is a basic rule that must be obeyed by the auditor and client. With the regulations regarding the restriction of this engagement time, it is expected that the auditors can maintain their independences to the clients and narrow the close relationship between two parties, so that the conflicts of interest do not occur between the company's management, shareholders and auditors (Ocktaviany, 2018).

\subsection{Auditor Switching}

According to Susilowati (2014), auditor switching is a change of auditor or Public Accounting Firm performed by the client company that can occur due to the provision of government regulation, or even the wishes of the company itself. According to Ruroh (2016) Auditor Switching is the change of auditor conducted by the client company in the next period. Auditor Switching is done to maintain the independence and objectivity of an auditor. Auditor switching can be caused by factors originating from the client or auditor. Auditor switching which is the behavior performed by the company to move auditor or the Public Accounting Firm can be caused by several factors, including the manager of two companies with different Public Accounting Firm, dissatisfaction to the previous Public Accounting Firm and merger between Public Accounting Firms (Halim, 1997: 79-80).

According to Nuryanti (2011) Auditor Switching may occur voluntary or mandatory. Mandatory auditor switching due to regulations that require companies to do so. However, on the contrary, if it is voluntary switching, then this is due to the causal factors from the client side (for example, financial difficulties, management failure, changes in ownership, Intial Public Offering, company growth, management turnover, institutional ownership, and so on) and from the auditor side (for example audit fee, audit opinion, audit opinion in the previous year, going concern opinion, firm size, and so on). In fact, the failure of several large companies in the west (Enron, WorldCom and Lehman Brothers) as well as in Malaysia (Perwaja Steel Berhad, Transmile Berhad Group, PKFZ Berhad) without the auditor's warning raises serious questions about the ethics of auditors and expect more professional auditor changes (Razana, Zuraidah, dan Arumega, 2019).

The indicators of auditor switching are measured by Auditor switching who audit the company's financial statements from the previous year. That information obtained from the issued company's financial statements, if the auditor stated in the company's financial statements is different from the previous year, then it can be concluded that there is an auditor switching.

\subsection{Financial Distress}

Hanafi (2007: 278) Financial distress can be described from two extreme points, which are short-term liquidity difficulty until it becomes insolvable. Short-term financial difficulties is usually short-term, but it can get worse. The indicator of financial difficulties can be seen from cash flow analysis, analysis of corporate strategy and the company's financial statements. According to Manurumg (2012: 96) who defines financial distress as a condition which the cash flow can not pay current liabilites. According to Wilkinns (1997) who defines that financial distress is encountered by the company if that company has a technical foul in liabilities and is predicted to go bankrupt in the period ahead.

According Peranian and Mimba (2018) Companies experiencing financial distress choose to replace its auditor for several reasons:

1) Companies with financial distress gain tendency of going concern audit opinion, so that the management choose to find an auditor who does not give a going concern audit opinion when financial distress, because the going concern opinion could be a negative signal to investors for investment decisions.

2) Companies with financial distress has decreased the company's reputation, so switch to the more reputable auditors can assure users of financial statements that the financial statements in accordance with the conditions of the company.

3) Companies that are experiencing financial distress can not afford to pay the audit fee is too expensive to switch to a cheaper KAP.

\subsection{Management Turnover}

According Wibowo (2011: 193) management turnover is a systematically process in applying the knowledge, tools and resources necessary to needed for change in people who will be affected by the change process. According Ruroh (2016) management turnover is the change of the board of directors of a corporate entity or a change of CEO (Chief Executive Officer) caused by the decision of the General Meeting of Shareholders (GMS) or the board of directors of his resignation. According to Ni Kadek (2010) management turnover is a change in the composition of the company's managerial, changes may be changes in the board of directors and board of commissioners. According Damayanti and Sudarma (2008), the change of management is the turn of the 
directors of the company that can be caused by a decision general meeting of shareholders or directors quit because of his own volition.

Management turnover at the company usually followed by a change in accounting and finance as well as changes in the selection of the auditor / KAP, the company will look for KAP in accordance with the new management policy. Indicators of management turnover can be seen from the turn of the board of directors who served, if the CEO who served on the financial statements different from the previous year can be concluded there has been management turnover.

\subsection{Audit Opinion}

According Islahuzzaman (2012: 292) the audit opinion is the opinion of the auditor of financial statements which have been audited. Meanwhile, according to Mulyadi (2014: 19) the audit opinion is opinion who given the auditor about fairness of financial statements of companies where auditors perform an audit. Company would want their financial statements have qualified opinion from KAP because opinion who given will determine the investment decisions of an external party. The audit opinion is also one of the basic information used by external users of financial statements as well be used as a basis for a decision to invest (Damayanti and Sudarma, 2007). If the auditor, give an opinion which is not in accordance with the company's hope, the company will replace its auditor.

(PSA 29 SA Section 508), there are five (5) types of the auditor's opinion:

1. Unqualified opinion

Unqualified opinion can be given if the auditor have been implemented or completed audit in accordance with auditing standards, the financial statements are presented in accordance with generally accepted accounting principles, and there are no conditions or specific circumstances that require explanatory language. Reasonable financial statements produced after going through (SA 411 paragraph 04), if:

a. The accounting principles selected and implemented has been generally accepted.

b. The accounting principles selected to the circumstances in question.

c. The financial statements and notes give sufficient information that may affect its use, understanding, and interpretation.

d. The information presented in the financial statements is classified and summarized correctly, which is not too detailed or too quick.

e. The financial statements reflect the transactions and events in a manner that presents the financial statement, results of operations and cash flows within the boundaries of rational and practical to achieve in the financial statements.

2. Unqualified Opinion with Explanatory Language

This opinion is given when the audit has been carried out or completed in accordance with auditing standards. Presentation of financial statements in conformity with generally accepted accounting principles, but there are certain circumstances or conditions that require explanatory language support. Conditions or circumstances that require additional explanatory language among others, can be described as follows:

a. The auditor's opinion is based partly on other indepanden the auditor's report. Auditors should explain this in a paragraph to emphasize the separation of responsibilities in the audit.

b. Deviations from the accounting principles established by the IAI. Such irregularities are irregularities which obliged be to do as not to mislead the users of financial statements.

3. Qualified Opinion According, SA 508 paragraph 38 to say that this type of opinion given if:

a. The absence of evidence sufficient competent or restriction on the material but does not affect the overall financial statements

b. The auditor believes that the financial statements from generally accepted accounting principles that material effect but does not affect the overall financial statements. Such irregularities is inadequate disclosures, as well as a change in accounting principle

\section{Adverse Opinion}

This opinion states that the financial statements do not present fairly the financial statement, results of operations and cash flows in accordance with generally accepted accounting principles. Auditors should explain reasons supporting the opinion is not fair, and the main impact of the causes given opinion on the financial statements. The explanation must be stated in a separate paragraph before paragraph opinions.

5. Disclaimer of Opinion or No Opinion

The statement did not give the auditor's opinion should be permitted if:

a. There are restrictions on the scope of the audit were very material either by the client or because of certain conditions

b. Auditor is not independent of the client 


\subsection{Reputation of KAP}

According to Juliana et al (2018) Reputation KAP is a big name who owned the auditor for the achievements and public trust achieved through his profession as an independent auditor. Adzrin, Ahmad, and Kamarudin (2014) states that the good reputation of the firm, the faster the audit process did because the firm of repute has employees that much, so it has a flexible schedule to complete the audit on time.

KAP is based on its reputation are classified into two are KAP big four and KAP non big four. If the firm is affiliated with the Big Four, the KAP has branches and client large companies and professionals have over 25 people. Meanwhile, if the firm is not affiliated with the Big Four, then the firm does not have branch offices and clients small companies and professionals of less than 25 people (Arens et al., 2014: 29). Big Four KAP are generally considered to be of higher quality than non Big Four KAP, large KAP are generally considered to be providers of higher audit quality and have a good reputation in the business world because auditors have characteristics that can be associated with good training quality. Large KAP will tend to maintain their independence. Big KAP (big four) is considered to have a better reputation in maintaining the level of independence than small KAP because large KAP provide many services clients so losing one client does not significantly on its revenue, but if a small KAP losing one client it is very meaningful because its clients is little (Shockley, 1981). Therefore, if a company is audited by a Big Four accounting firm, the company is likely to maintain KAP Big Four than non-Big Four.

KAP in Indonesia, which is affiliated with the Big Four Auditors by (www.wikipedia.com) is as follows:

1. KAP Hans Tuanakota, Mustafa \& Halim, Osman Ramli Satrio \& Partners, Osman Bing Satrio \& associates affiliated with Deloitte Touche Tohmatsu (Deloitte).

2. KAP Prasetio, Sarwoko Sandjaja; Purwantono, Sarwoko \& Sandjaja affiliated with Ernest \& Young (EY).

3. KAP Siddharta, Siddharta \& Widjaja affiliated with Klynveld Peat Marwick Goerdeler (KPMG).

4. Haryanto Sahari \& Partners; Tanudiredja, Wibisana \& Partners, Drs. Hadi Susanto \& Partners affiliated with Pricewaterhouse Cooper (PwC).

Not only Public Accounting Firm's auditors, the government auditors (hereafter referred to as auditors) become important agents to the government in ensuring a good perception and also a good reputation in conduct of the government agencie (Razana, Nordayana, dan Arumega, 2019)

\section{Research Hypothesis}

3.1 Effect of Financial Distress on Auditor Switching

Financial distressis is condition in which the company has unsanitary conditions or in financial distress so worried would bankrupt (Wijaya, 2011). Companies that are experiencing financial distress tend to improve the evaluation of subjectivity and prudence auditor, and therefore in such circumstances, the company will perform the auditor switching in hopes of getting a better opinion and financial advice to help firms out of the problem of financial distress.

Financial distress can also be caused by high audit fees charged to the company while the company's condition is unstable when experiencing financial distress therefore the company will prefer to switch to a new Public Accounting Firm that can provide audit services at a cost that is not too high so that it can still be reached by the company. This is in line with the research of Nasser et al. (2006) which states that client companies that are on the verge of bankruptcy due to being experiencing financial distress are likely to make more frequent changes in the Public Accounting Firm than companies that do not experience financial distress (financial distress).

Financial distress can also be caused because the company no longer afford to pay the cost of the audit.

The results are consistent with research conducted Hudaib and Cooke (2005) andWidyanti and Badera (2016) which states that the financial distress affect the auditor switching.

H1: Financial Distress on the auditor switching

\subsection{Effect of Management turnover on Auditor Switching}

According Damayanti and Sudarma (2007) management turnover in the company can be followed by a change of policy in accounting, finance, and the selection of the Firm or its auditors. With the new management turnover, can create new policy because new management may be have different opinion with the old managementto manage company. This new policy have function to increase quakity and company standard in the next leadership.

Relationship between auditor with the client was bilateral relationship, where the clien or company are renting auditor service for auditing financial statement so that financial statement was relevant and reliable. This is done to be able to attract investors in investing in the companies they manage. Therefore, the new management will appoint a new auditor who is more able to cooperate and more able to provide opinions as expected by management, accompanied by a separate preference about the auditor to be used. So that 
management turnover the client company will look for auditors that are in line with its accounting policies and reporting. In addition, the company's new management will prefer qualified and competent auditors to audit the company's financial statements. This is in line with the argument of Schwartz \& Menon (1985) which states that the change of management in a company allows new managers to choose auditors who have good relations with the company or choose auditors who can respect their accounting choices and policies.

The results are consistent with research conducted M Hudaib and Cooke (2005) and Al Azhar (2015) and shows the influence of management changes on Auditor Switching.

$\mathrm{H} 2$ : Substitution Manajamen on the auditor switching.

\subsection{Audit Opinion on Auditor Switching}

According to Mulyadi (2014: 19) audit opinion is given the auditor's opinion on the fairness of financial statements of companies where auditors perform an audit. The audit opinion is important information for shareholders or other parties with an interest in the company. The audit opinion is also one of the basic information used by external users of financial statements as well be used as a basis for a decision to invest (Damayanti and Sudarma, 2007). Expressions of opinion of an auditor can affect the view of shareholders on management performance in managing the company. Therefore, management tends to avoid or dislike a qualified opinion because it will reduce the credibility of the company's financial statements.

The same opinion was expressed by Andra (2012) managers believe that audit opinions will affect stock prices and financing capacity, so qualified opinions will likely effect the company's decision to terminate the contract with the auditor. Another thing that causes a company to do auditor switching if the previous year's audit opinion is not in accordance with the wishes of the company's management. This is because companies avoid the appearance of qualified opinions in their financial statements. Therefore, if the client company gets an unexpected audit opinion on its financial statements it will tend to do auditor switching.

The results are consistent with research conducted Hudaib \& Cooke (2005) and Faradilla (2016) states the audit opinion on the Auditor Switching effect.

H3: Audit Opinion on the auditor switching

\subsection{Effect of Firm Reputation on Auditor Switching}

According to Juliana et al (2018) Reputation KAP is a big name who owned the auditor for the achievements and public trust achieved through his profession as an independent auditor. Investors will be more likely to believe in the accounting data resulting from the auditors of repute or KAP affiliated with the big four this because KAP Big Four are considered to have a higher quality and have better skills and generate audit quality higher than KAP Non Big Four. This is in line with research Craswell et. al. (1995) which states that the client usually perceive that auditors from the Office of Public Accountants large and have an affiliation with a public accounting firm Internasionallah which have higher quality because the auditor has characteristics that can be associated with quality, such as training, and international recognition. Hence Companies that want a reliable audit quality will naturally choose the auditors of the KAP which has a high quality. If the company uses a bad reputation, then the chances of switching auditors by the company will be even greater.

The results are consistent with research conductedDamayanti and Sudarma (2008) and Pawitri (2015), Reputation KAP demonstrate an effect on Auditor Switching.

H4: Firm Reputation on the auditor switching

\section{Research Model}

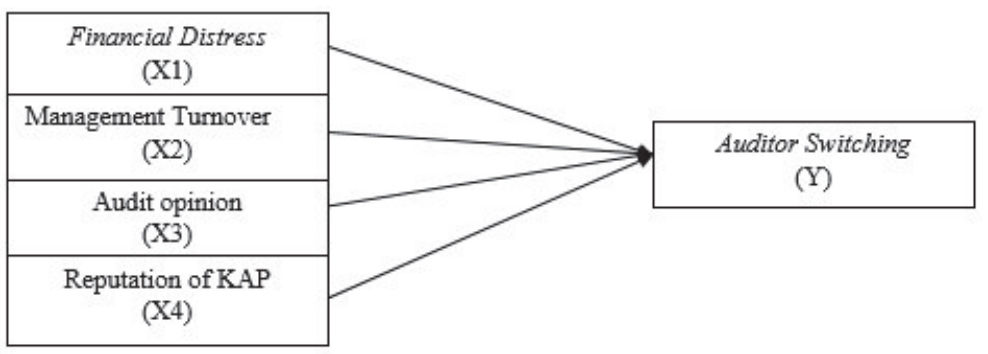

Figure1. Research Model

\section{Research Methods}

The population in this research used all companies listed in Indonesia Stock Exchange. The author uses the data for 4-year observation period, namely from the period 2014-2017, the total sample of the observations in this research amounted to 260 observations. Sampling was determined using purposive sampling method. 


\subsection{Data analysis method}

The analytical tool used in this research is the logistic regression analysis (logistic regression). The reason the use of logistic regression analysis (logistic regression) is for dichotomous dependent variable (doing Auditor Switching or not doing Auditor Switching).

Logistic regression models in this study are as follows:

$$
\mathrm{SWITCH}=\alpha+\mathrm{b} 1 \mathrm{FD}+\mathrm{b} 2 \mathrm{PM}+\mathrm{b} 3 \mathrm{OPINI}+\mathrm{b} 4 \mathrm{RKAP}+\mathrm{e}
$$

FD

PM

OPINION

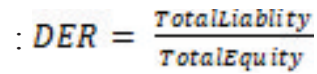

CBP : If the client company to replace the chief executive then given the value 1 . Meanwhile, if the client does not replace the company's chief executive then given the value 0 .

O.
If the company gets the unqualified opinion given the code 1 and if they received unqualified opinions in addition to the coded 0

If the company is audited by KAP KAP affiliated with the big four rated 1 and if not then rated 0 .

Table 1. Estimated Descriptive Statictics

\begin{tabular}{|l|r|r|r|r|r|}
\hline \multicolumn{7}{|c|}{ descriptive Statistics } & \multicolumn{1}{c|}{ Std. deviation } \\
\hline & $\mathrm{N}$ & \multicolumn{1}{|c|}{ Minimum } & \multicolumn{1}{c|}{ Maximum } & \multicolumn{1}{c|}{ mean } & .48025 \\
\hline US & 260 & .00 & $1: 00$ & .6423 & 3.88653998 \\
\hline FD & 260 & .04029 & 39.48579 & 2.3485238 & .46402 \\
\hline PM & 260 & .00 & $1: 00$ & .3115 & .49666 \\
\hline OP & 260 & .00 & $1: 00$ & .5654 & .48921 \\
\hline reputation KAP & 260 & .00 & $1: 00$ & .3923 & \\
\hline Valid N (listwise) & 260 & & & & \\
\hline
\end{tabular}

Variable financial distress as the independent variable is proxied by using DER. The minimum value of this variable at 0.04029 , the maximum value of 39.48579 , The average value of 2.3485238 , And the standard deviation value of 3.88653998 .

Table 2. Estimated AS

\begin{tabular}{|r|l|r|r|r|r|}
\hline \multicolumn{9}{|c|}{ AS } \\
\hline \multirow{3}{*}{ Valid } & Not Doing Auditor Switching & Frequency & Percent & valid Percent & Cumulative Percent \\
\cline { 2 - 6 } & Doing Auditor Switching & 93 & 35.8 & 35.8 & 35.8 \\
\cline { 2 - 6 } & Total & 167 & 64.2 & 64.2 & 100.0 \\
\hline
\end{tabular}

The results of the analysis using descriptive analysis of auditor switching variable indicates the samples that do not perform switching auditors in this research is 93 observations or $35.8 \%$ and the samples that do auditor switching are 167 observations, or $64.2 \%$.

Table 3. Estimated PM

\begin{tabular}{|c|c|c|c|c|c|}
\hline \multicolumn{6}{|c|}{ PM } \\
\hline & & frequency & Percent & $\begin{array}{c}\text { valid } \\
\text { Percent }\end{array}$ & $\begin{array}{l}\text { Cumulative } \\
\text { Percent }\end{array}$ \\
\hline \multirow[t]{3}{*}{ Valid } & $\begin{array}{l}\text { Not Doing Change of } \\
\text { Management }\end{array}$ & 179 & 68.8 & 68.8 & 68.8 \\
\hline & Doing Substitution Management & 81 & 31.2 & 31.2 & 100.0 \\
\hline & Total & 260 & 100.0 & 100.0 & \\
\hline
\end{tabular}

The results of the analysis using descriptive analysis of management turnover variable indicates the samples that do not perform management turnover in this research were 179 observations or $68.8 \%$ and the samples that perform management turnover is 81 observations or $31.2 \%$. 
Table 4. Estimated Audit Opinion

\begin{tabular}{|l|l|r|r|r|c|}
\hline \multicolumn{2}{|c|}{ AUDIT OPINION } & valid Percent & $\begin{array}{c}\text { Cumulative } \\
\text { Percent }\end{array}$ \\
\hline \multirow{3}{*}{ valid } & frequency & Percent & 43.5 & 43.5 \\
& $\begin{array}{l}\text { Besides getting unqualified } \\
\text { opinion }\end{array}$ & 113 & 43.5 & 56.5 & 100.0 \\
\cline { 2 - 6 } & Getting unqualified opinion & 147 & 56.5 & 100.0 & \\
\cline { 2 - 6 } & Total & 260 & 100.0 & 4 & \\
\hline
\end{tabular}

The results of the analysis using descriptive analysis of variables audit opinion indicates the samples that receive unqualified opinions other than 113 observations, or $43.5 \%$ and the samples to obtain unqualified opinion that is other than 147 observations, or $56.5 \%$.

Table 5. Estimated Reputation of KAP

\begin{tabular}{|l|l|r|r|r|r|}
\hline \multicolumn{2}{|c|}{ Reputation of KAP } & \multicolumn{1}{|c|}{ Percent } & valid Percent & $\begin{array}{c}\text { Cumulative } \\
\text { Percent }\end{array}$ \\
\hline \multirow{3}{*}{ valid } & $\begin{array}{l}\text { frequency } \\
\text { Non Big Four accounting } \\
\text { firm }\end{array}$ & 158 & 60.8 & 60.8 & 60.8 \\
\cline { 2 - 6 } & KAP Big Four & 102 & 39.2 & 39.2 & 100.0 \\
\cline { 2 - 6 } & Total & 260 & 100.0 & 100.0 & \\
\hline
\end{tabular}

The results of the analysis using descriptive analysis of the firm's reputation moderating variable indicates the samples that did not cooperate with KAP Big Four are 158 observations, or $60.8 \%$ and the samples in cooperation with KAP Big Four are 102 observations, or $39.2 \%$.

\subsection{Test Results Overall Model (Overall Model Fit)}

Table 6. Estimated Overall Model

\begin{tabular}{|c|c|c|c|c|c|c|c|}
\hline \multirow{2}{*}{\multicolumn{2}{|c|}{ Iteration }} & \multirow{3}{*}{$\begin{array}{c}\begin{array}{c}-2 \log \\
\text { likelihood }\end{array} \\
321776\end{array}$} & \multirow{2}{*}{\multicolumn{5}{|c|}{ coefficients }} \\
\hline & & & & & & & \\
\hline \multirow{4}{*}{$\begin{array}{l}\text { Step } \\
1\end{array}$} & 1 & & 390 & .052 & .544 & -.554 & .511 \\
\hline & 2 & 320392 & .353 & .091 & .650 & -.647 & .601 \\
\hline & 3 & 320369 & .344 & .098 & .657 & -.653 & .608 \\
\hline & 4 & 320369 & .344 & .098 & .657 & -.653 & .608 \\
\hline
\end{tabular}

a. Method: Enter

b. Constant is included in the models.

c. Initial -2 Log Likelihood: 339081

d. Estimation terminated at iteration number 4 Because the parameter estimates changed by less than .001 .

Value -2LogL initial amounted to 339.081. After four independent variables entered the final value has decreased to 320 369. Decrease Likelihood (-2LogL) shows a regression model that better or in other words the hypothesized model fits the data.

\subsection{Test Results Hosmer and Lemeshow's}

Table 7. Estimated Hosmer and Lemeshow's

\begin{tabular}{|l|r|r|rr|}
\hline Step & Chi-square & df & \multicolumn{1}{|c|}{ Sig. } \\
\hline 1 & 8147 & & 8 & .419 \\
\hline
\end{tabular}

Statistical tests showed the Chi-square value amounted to 8.147 with a significance of 0.419 . Based on these results, because the significance value greater than 0.05 , it can be concluded that this model can be accepted because it fit with the data observations.

5.4 Test Results The coefficient of determination (Nagelkerke's R Square)

Table 8. Estimated Coefficient of Determination

\begin{tabular}{|l|r|r|c|}
\hline Step & $-2 \log$ likelihood & Cox \& Snell R Square & Nagelkerke R Square \\
\hline 1 & $320.369 \mathrm{a}$ & .069 & .095 \\
\hline \multicolumn{2}{|r}{ a. Estimation terminated at iteration number 4 Because the parameter estimates changed by less than .001. }
\end{tabular}

It can be seen that the value Nagelkerke's R Square together the variables of financial distress, the change of management, audit opinion and reputation of the firm has been able to explain the diversity of the data in the variable switching auditors of $9.5 \%$, while the remaining $90.5 \%$ is explained by other variables outside our model. 


\subsection{Test Result Matrix Classification}

Table 9. Estimated Matrix Classification

\begin{tabular}{|c|c|c|c|c|c|}
\hline & \multirow{3}{*}{\multicolumn{2}{|c|}{ Observed }} & \multicolumn{3}{|c|}{ predicted } \\
\hline & & & \multicolumn{2}{|c|}{ US } & \multirow{2}{*}{$\begin{array}{l}\text { Percentage } \\
\text { Correct }\end{array}$} \\
\hline & & & $\begin{array}{l}\text { Not Doing } \\
\text { Auditor } \\
\text { Switching }\end{array}$ & $\begin{array}{l}\text { Doing Auditor } \\
\text { Switching }\end{array}$ & \\
\hline \multirow[t]{3}{*}{ Step 1} & \multirow[t]{2}{*}{ US } & Not Doing Auditor Switching & 25 & 68 & 26.9 \\
\hline & & Doing Auditor Switching & 19 & 148 & 88.6 \\
\hline & \multicolumn{2}{|c|}{ Overall Percentage } & & & 66.5 \\
\hline
\end{tabular}

a.

The cut value is .500

The ability to predict the regression model for the possibility that the company perform switching auditors amounted to $88.6 \%$. So it can be seen that by using the regression model, there are as many as 162 companies, or $88.6 \%$, which is predicted to perform switching from recent auditor total of 167 companies that perform switching auditors. While the ability to predict the regression model for the possibility of companies do not perform switching auditors amounted to $26.9 \%$. So it can be seen that by using the regression model, there are as many as 25 companies, or $26.9 \%$, which is predicted to not perform switching auditors of the total 93 companies that do not perform switching auditors.

\subsection{Logistic Regression Results}

Testing the hypothesis in this study was to test the effect of independent variables, namely the audit opinion, financial distress and Change of Management as the independent variable on the dependent variable, namely the auditor switching, using a significance test of regression coefficients and the results that are formed can be seen from the table below.

Table 10. Estimated Regresion Logistic

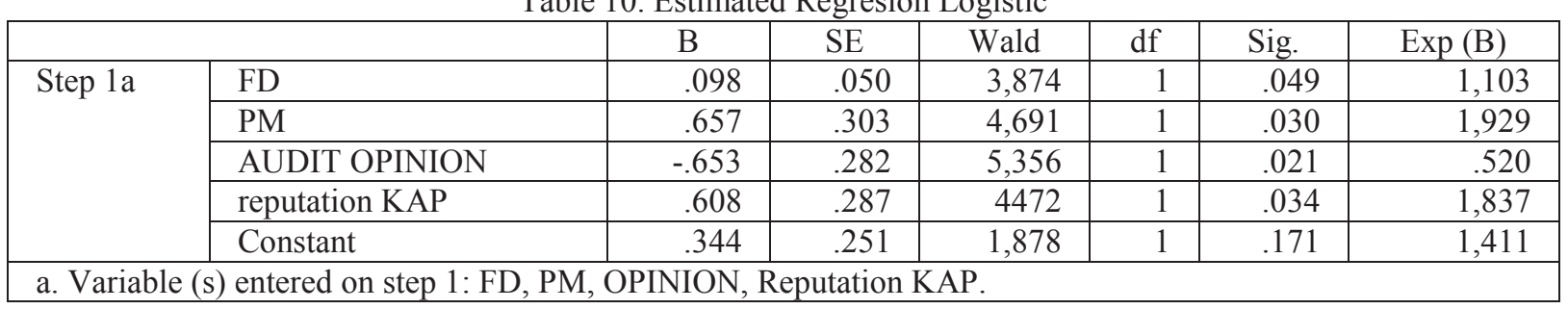

\section{Result and Discussion}

\subsection{First hypothesis}

Financial distress variables have a significance value of 0.049 is less than 0.05 . Due to significant levels of less than 0.05 , the first hypothesis in this study received and can be stated that the financial distress switching has affect on auditor switching. Its indicates that the sample firms tend to make the turn auditor if financial distress to avoid going concern opinion it is appropriate theory Peranian and neem (2018) which states that Companies with financial distress gain tendency of going concern audit opinion, so that the management opted to find an auditor who does not give a going concern audit opinion when financial difficulties arise, because the going concern opinion could be a negative signal to investors for investment decisions

Other things can also be caused by companies that are experiencing financial distress can not afford to pay the audit fee. Audit fee is usually measured in working hours auditor. When using a new auditor, the new auditor should seek information about new clients, understand the client's business environment, which will extend the hours of work of auditors, this will lead to an increase in audit fees (Lesmana, 2016). Increaseaudit fee must cause decreased ability to finance companies that no longer have the ability to pay the audit fees charged by the Firm therefore, the company would prefer to switch to a new public accounting firm that can provide audit services at a cost that is not too high so that they can be reached by the company. This is in line with research Nasser et al. (2006) and Hudaib and Cooke (2005) which states that the company's clients verge of bankruptcy as a result are experiencing financial difficulties (financial distress) tend to be more frequent replacement than the company's public accounting firm that is not experiencing financial difficulties (financial distress).

The results are consistent with research conducted Hudaib and Cooke (2005) and Widyanti and Badera (2016) which states that the financial distress affect the auditor switching.

\subsection{Second hypothesis}

Variable management turnover has a significance value of 0,030 is smaller than 0.05 . Due to significant levels of 
less than 0.05 , then the second hypothesis in this study received and can be stated that the management changes affect the auditor switching. This indicates that the sample firms tend to make the turn auditor if the auditor were long considered not have competent and qualified companies require auditors. This is in line with research Joher et al (2000) suggest that management requires more qualified auditor and able to meet the company's rapid growth.

Management changes usually lead to a new policy in the company due to the new management is likely to have a slightly different view with the old management in managing the company. Policy - the new policy is intended by the new management to improve the quality and quality standards of the company during his leadership sonew management will hire auditors to audit the financial statements in order that the financial statements relavan and reliable. This is done in order to attract investors to invest in the company they manage. Therefore manajamen which will appoint a new auditor that more could be invited to cooperate and be able to give their opinions as expected by management, along with the preference of its own on the auditor that will be used so that with the change of management of the company's clients will be looking for an auditor that is consistent with the policies and reporting accounting (Sinarwati, 2010). Schwartz and Menon (1985) also stated that a change of management in a company enabling a new manager to select auditors who have a good relationship with the company or choose an auditor who can respect the choices and their accounting policies.In addition, the new management of the company would prefer qualified and competent auditors to perform audits of financial statements of the company. If the auditors assess the management is incompetent in performing its duties, it will make the management thinking to do auditor switching.

This study is in line with research conducted by M Hudaib and Cooke (2005) and Nazri et al (2012) which states that the change of management affect the auditor switching.

\subsection{Third hypothesis}

Variable audit opinion has a significance value of 0.021 is less than 0.05 . Due to significant levels of less than 0.05 , then the third hypothesis in this study received and can be stated that the audit opinion affect the auditor switching. This indicates that the sample firms tend to make the turn auditor if the sample firms acquire qualified opinion or opinions that are not expected. This is in line with researchAndra (2012) which states that managers believe that the audit opinions were unfavorable would affect the stock price and the financing capacity, so that the qualified opinion is likely to affect the company's decision to terminate the contract with the auditor.

The audit opinion is a statement of the auditor on the fairness of the financial statements after conducting an audit of the fairness of the financial statements of the company. Clients would want to get their financial statements WTP opinion (unqualified) from KAP for a given opinion will affect the investment decisions of an external party. This is in line with the statementDamayanti and Sudarma (2007) which states that the audit opinion is one of the basic information used by external users of financial statements as well be used as a basis for a decision to invest., Another thing that causes a company do if the switching auditors prior year's audit opinion expressed wishes of the management company. This is because companies avoid the appearance of a qualified opinion on their financial statements. Therefore, If the company gets an unexpected audit opinion on its financial statements would tend to make the auditor switching.

The results are consistent with research conducted Hudaib \& Cooke (2005) and Faradilla (2016) states the audit opinion on the Auditor Switching effect.

\subsection{Fourth hypothesis}

Variable reputation of KAP has a significance value of 0.034 is less than 0.05 . Due to significant levels of less than 0.05 , then the third hypothesis in this study received and can be stated that the reputation of KAP affect the auditor switching. This indicates that the sample firms tend to make the turn auditor to KAP affiliated with the Big Four to improve the quality of financial statements and the company's reputation in the eyes of users of financial statements. This is in line with research Nasser et al., (2006) which states that the auditor in good standing have the skills audit is higher and will produce quality audit in better with so companies can attract potential investors so that public trust in the company will increase.

KAP is based on its reputation are classified into two is KAP big four and KAP non big four, KAP Big Four generally considered better than non-Big Four accounting firm because it is generally regarded as a quality provider of audithigher and have a good reputation in the business world as well. Reputable auditors who already have characteristics that can be attributed to the quality of training is good so great KAP will tend to maintain their independence, KAP great (big four) perceived to be having a good reputation in memelihari level indepedensinya compared with KAP small because KAP big provides services to many clients so that the loss of the clients are not so influential on earnings, but if KAP small loss of one client is very meaningful because client slightly (Shockley, 1981). This is in line with research Wijayani and Januarti (2011) which states that the firm that has been reputed to have a better ability to audit than KAP is not standing, so as to produce the quality of audits and the independence of the higher. Therefore, if a companywho have used the services of the big four 
accounting firm with a reputation is less likely to change KAP (Damayanti and Sudarma, 2008). And if the company uses a bad reputation, then the chances of switching auditors by the company will be even greater.

The results are consistent with research conducted Damayanti and Sudarma (2008) and Pawitri (2015), Reputation KAP has an effect on Auditor Switching.

\section{Conclusion, Limitations, and Recommendation}

Based on results of research, it can be concluded that financial distress, management turnover, audit opinion and reputation of public accounting firm affect the auditor switching on companies listed on the Indonesia Stock Exchange in 2014-2017.

This study has limitations that can be taken into consideration for further research in order to obtain better results in the future, including: the selection of independent variables that are thought to influence financial distress, management turnover, audit opinion and reputation of public accounting firm and this study uses secondary data so that it does not obtain direct perception from the company management, auditors, and investors.

Based on the results of the analysis of the discussion as well as some conclusions and limitations in this study, as for the suggestions that can be given in order to get better results, including: it is expected that in subsequent studies to add a number of other variables that are thought to influence auditor switching from both internal and external factors, for companies to be more careful in making decisions to make auditor changes, and for prospective investors, before investing their capital in a company, they must first pay attention to the financial statements issued by the company so that they are not wrong in making investment decisions.

\section{References}

Agoes, Sukrisno. 2012. "Auditing: A Practical Guide By Public Accountant Examination Accounting". Volume 1, Fourth Edition, Salemba Four: Jakarta.

Arens, Alvin A. Randal J. Elder and Mark S. Beasley, 2014. The Auditing and Assurance Services (translation), Fifteenth Edition. Jakarta: Erland

Craswell, AT 1998. The Association between qualified opinion and auditor switches. Acoocunting and Business Research. 19th. pp. 23-31.

Damayanti, S. and M. Sudarma. 2007. "Factors Affecting Public Accounting Firm Moving Company". National Symposium Accounting 11, Pontianak.

Faradila, Yuka and M. Rizal Yahya, 2016. Influence of Audit Opinion, Financial Distress and Client Company Growth Against Auditor Switching, Student Scientific Journal Economic Accounting (JIMEKA), Vol. 1, 1, p. 81-100.

Ghozali, Imam. 2018. Applications Multivariate Analysis with IBM SPSS 25. Program Publisher Agency Diponegoro University Semarang.

Halim, A. 1997. Fundamentals of Financial Statement Audit. Yogyakarta: Publishing \& Printing Unit (UPP) AMP YKPN.

Hanafi, M and Abdul Mahmud and Abdul Halim. 2007. Analysis of Financial Statements. Yogyakarta: YPP YKPN.

Hudaib, M. and TE Cooke. 2005. "The Impact of Managing Director Changes and Financial Distress on Audit Qualification and Auditor Switching". Journal of Business Finance \& Accounting, Vol. 32, No. 9/10, pp. 1703-1739.

Islahuzzaman, 2012. The terms of Accounting and Auditing, the First Edition. Jakarta: Earth Literacy.

Jensen, MC and WH Meckling. 1976. Theory of the Firm: Managerial Behavior, Agency Cost and Ownership Structure. Journal of Financial Economics, Vol. 3, pp. 305-316.

Johari, Razana Juhaida, Nordayana Sri Ridzoan dan Arumega Zarefar. 2019. The Influence of Work Overload, Time Pressure and Social Influence Pressure on Auditors' Job Performance. International Journal of Financial Research Vol. 10, No. 3, pp. 88-89.

Johari, Razana Juhaida, Zuraidah Mohd Sanusi dan Arumega Zarefar. 2019. Auditor ${ }^{\text {ee }}$ Ethical Judgments: The Influence of Moral Intensity, Ethical Orientation and Client Importance. International Journal of Financial Research Vol. 10, No. 3, pp. 77-78.

L, Al Azhar (2015). Influence of Financial Distress, Management Turnover and Audit Opinion to the Auditor Switching (Empirical Study on Manufacturing Companies Listed on the Stock Exchange During the Period 2011-2013). Research Journal of Finance and Accounting. Vol.6, No.24, pp. 120-126.

Manurung, Adler Haymans. 2012. The Theory of Corporate Finance. Jakarta: Adler Manurung Press.

Nazri, Sharifah NFSM; Smith, Malcolm; Ismail, Zubaidah. 2012. "Factors Influencing Auditor Change: Evidence From Malaysia". Asian Review of Accounting. Vol 20 No. 3, pp. 222-240.

Nuryanti, Lely. 2012. Effect of Audit Opinion and Corporate Growth Rate Of Change of Auditor. Journal of Accounting UNESA, State University of Surabaya. Vol 1, No 1. 
Ocktaviany, Ayu Widy, 2018. Influence of Client Company Size, Change of Management, Institutional Ownership, Profitability and complexity of the Company's Auditor Switching (Empirical Study On LQ-45 Company Listed on the Indonesia Stock Exchange (Bei) Year 2011-2016), Jom FEB Volume 1 Issue 1.

Pawitri, Made Puspa. 2015. Effect of Delay Audit, Audit Opinion, Reputation Auditor and Management Substitution on Voluntary Auditor Switching. Journal of Accounting and Business, 10 (1), Page 214-299.

Peranian, Ngurah Agung and Ni Putu Sri Harta neem. 2018. Effects of Good Corporate Governance, Financial Distress, and Return On Equity on Voluntary Auditor Switching. E-Journal of Accounting, University of Udayana. Vol.23.2, pp. 1574-1599

Ruroh, Farida Mas, 2016. Effect of Change of Management, Financial Difficulties, Kap Size, And Audit Of Auditor Switching Delay Case Study at Manufacturing Companies Listed on the Indonesia Stock Exchange Year 2012-2015, Thesis. Yogyakarta: Yogyakarta State University.

Shockley, Randolph A. 1981. Perceptions of Independence: An Empirical Analysis. The Accounting Review. pp. 785-800

Susilowati, Evi, 2014. Effect of Going Concern Opinion and profitability of the Company to the Auditor Switching with Financial Distress as Variable Moderation (Empirical Study on Manufacturing Company Sub Sector Pharmaceutical, Food and Beverage listed on the Stock Exchange in 2010-2014). Proceedings of Accounting. Vol 3, No 2, Page 244-250

Wibowo, 2011. Performance Management, Jakarta:Rajawali Press.

Widyanti, AA Sagung Supreme wife, I Dewa Nyoman Badera. 2016 "Auditor's reputation as a moderating Influence of Financial Distress on Auditor Switching", Bali.Vol.16 Udayana University, No. 3, Page 18001828

Wilkins. Michael S. 1997. Technical Default, Auditors' Decisions and Future Financial Distress. Accounting Horizons. Vol 11, No 4, Page 44-48

Yuliani, Riska Edi Sukarmanto and Pupung Purnamasari. (2018). Substitution Effect of Management and Audit Delay towards Substitution KAP KAP with a reputation as a Variable Moderation. Journal of Accounting, Bandung Islamic University, Volume 4, \# 1, Page 261-268

2002. The Ministry of Finance Minister Finance Minister Decree No. 423 / KMK.06 / 2002 on Public Accounting Services. Jakarta

2003. The Ministry of Finance Minister Finance Minister Decree No. 359 / KMK.06 / 2003 on Public Accounting Services. Jakarta

2008. The Ministry of Finance Minister Finance Minister Decree No. 17 / PMK.01 / 2008 on Public Accounting Services. Jakarta

Department of the Ministry of Finance, 2015. The Indonesian Government Regulation No. 20 of 2015 "On Public Accounting Practices". Jakarta.

Finance seconds, "Troubled Financial Statements, Inovisi Change of Auditors", 2015 in http://m.detik.com

The Big Four Auditors. Obtained fromhttp://www.wikipedia.com

www.idx.co.id 